\title{
Determinanty finansowe wzrostu inwestycji jednostek samorządu terytorialnego
}

\begin{abstract}
Streszczenie
Determinanty finansowe związane z sytuacją budżetową jednostek samorządu terytorialnego odgrywają najważniejszą rolę wśród całokształtu czynników wpływających na podejmowanie i prowadzenie inwestycji przez jednostki terytorialne. Finanse są kluczowym elementem funkcjonowania jednostek samorządu terytorialnego oraz podstawowym wyznacznikiem realności i powodzenia każdej inwestycji. Celem artykułu jest przedstawienie determinant finansowych związanych z sytuacją budżetową jednostek samorządu terytorialnego w Polsce i ich wpływu na realizację inwestycji przez te podmioty. Charakterystyce poddano wydatki na inwestycje, dochody własne, wynik budżetów ze szczególnym uwzględnieniem nadwyżki operacyjnej.
\end{abstract}

Słowa kluczowe: jednostki samorządu terytorialnego, inwestycje, wydatki na inwestycje, dochody własne, wynik budżetów, nadwyżka operacyjna

\section{Financial determinants of investment growth in territorial self-government units}

\begin{abstract}
Financial determinants related to the budgetary situation of territorial self-government units play the most important role among all the factors affecting the undertaking and conducting of investments by territorial units. Finances are a key element in functioning of territorial self-government units as well as the primary determinant of viability and success of any investment. The objective of this article is to present financial determinants associated with the budgetary situation of territorial self-government units in Poland and their effects on investment execution by these entities. Consequently, investment expenditure, own income, and budgetary result with particular attention to operating surplus have been characterized.
\end{abstract}

Keywords: territorial self-government units, investments, investment expenditure, own income, budgetary result, operating surplus 
Determinanty finansowe związane z sytuacją budżetową jednostek samorządu terytorialnego odgrywają najważniejszą rolę wśród całokształtu czynników ${ }^{1}$ wpływających na podejmowanie i prowadzenie inwestycji przez jednostki terytorialne. Finanse są kluczowym elementem funkcjonowania jednostek samorządu terytorialnego oraz podstawowym wyznacznikiem realności i powodzenia każdej inwestycji. Stan finansów jest z jednej strony kształtowany przez wielkość dochodów, a z drugiej poprzez ukierunkowanie wydatków. Należy zaakcentować, że dochody oraz wydatki jednostek samorządu terytorialnego są zróżnicowane, ponieważ są następstwem m.in. różnego poziomu rozwoju społeczno-gospodarczego poszczególnych części państwa². Ponadto uwzględnić należy relacje między kwotą dochodów i sumą wydatków, co jest źródłem informacji o stanie nierównowagi w budżetach jednostek terytorialnych. Co więcej, sytuacja finansowa jednostek samorządu terytorialnego wpływa na rozwój innych dziedzin ich funkcjonowania i jest źródłem informacji o potencjale rozwoju gospodarczego oraz pozwala kompleksowo oceniać działanie tych podmiotów ${ }^{3}$.

Celem artykułu jest przedstawienie determinant finansowych związanych z sytuacją budżetową jednostek samorządu terytorialnego w Polsce i ich wpływu na realizację inwestycji przez te podmioty. $\mathrm{W}$ związku z powyższym charakterystyce poddano wydatki na inwestycje, dochody własne, wynik budżetów ze szczególnym uwzględnieniem nadwyżki operacyjnej. Ze względu na ograniczone ramy niniejszego opracowania przedmiotem analizy nie są zagadnienia związane z dostępnością i pozyskiwaniem środków finansowych ze źródeł zagranicznych.

\section{Wydatki na inwestycje w budżetach jednostek samorządu terytorialnego}

Istotne znaczenie ma finansowanie działalności podejmowanej przez jednostki samorządu terytorialnego. Wydatki ponoszone przez jednostki samorządu terytorialnego

1 Oprócz czynników finansowych wyodrębnić można determinanty: społeczno-gospodarcze, prawne, polityczno-administracyjne, techniczne, geograficzne, historyczne oraz kulturowe. M. Dworakowska, Determinanty rozwoju aktywności inwestycyjnej miast na prawach powiatu, w: Instrumenty zarzadzania finansami jednostek samorzadu terytorialnego, red. D. Wyszkowska, Wydawnictwo Uniwersytetu w Białymstoku, Białystok 2013, s. 122-130. Czynniki finansowe są powiązane z tymi o charakterze społeczno-gospodarczym i łącznie stanowią podstawę ekonomiczną uwarunkowań.

2 Różnice w poziomie rozwoju społeczno-gospodarczego w Polsce doskonale widać dzięki zestawieniu poziomu rozwoju województw leżących na wschodzie, z tymi z zachodniej i centralnej części państwa. O konieczności szybkiego ograniczenia tych dysproporcji w rozwoju świadczy wyodrębnienie w ramach funduszy unijnych specjalnego programu operacyjnego służącego wsparciu województw wschodnich. Dedykowany temu był Program Operacyjny Rozwój Polski Wschodniej, który funkcjonował w latach 2007-2013 i działający w obecnej perspektywie finansowej Program Operacyjny Polska Wschodnia.

3 E. Wojciechowski, Zarządzanie w samorzadzie terytorialnym, Difin, Warszawa 2012, s. 234-235. 
pozwalają zaspokajać zbiorowe potrzeby społeczności lokalnych i regionalnych. Kierunki realizacji wydatków budżetowych zależą od priorytetów wydatkowych danej jednostki terytorialnej, które są określane w ramach katalogu zadań publicznych przyznanych do realizacji jednostkom samorządu terytorialnego. Zadania te mogą mieć różną specyfikę - wyodrębnia się wśród nich w szczególności te o charakterze inwestycyjnym i pozainwestycyjnym. Dokonywanie wydatków budżetowych zależy przede wszystkim od kwoty pozyskanych dochodów budżetowych.

Wydatki budżetowe jednostek samorządu terytorialnego dzieli się na dwie grupy. Jedną z nich są wydatki majątkowe, obejmujące inwestycje i zakupy inwestycyjne, zakup oraz objęcie akcji i udziałów, wniesienie wkładów do spółek prawa handlowego. Drugą grupę wydatków stanowią wydatki bieżące, które dotyczą pozostałych wydatków budżetowych ${ }^{4}$. Wydatki bieżące służą finansowaniu funkcjonowania jednostki terytorialnej i umożliwiają utrzymanie oraz eksploatację powstałej dotychczas infrastruktury. Wydatki majątkowe są natomiast praktycznie w całości przeznaczane na inwestycje jednostek samorządu terytorialnego. Wydatki na inwestycje są też nazywane wydatkami majątkowymi inwestycyjnymi, co pozwala podkreślić, że są zasadniczą częścią wydatków majątkowych. Ich realizacja ma kluczowe znaczenie dla ograniczania opóźnień w rozwoju jednostek samorządu terytorialnego, a kolejne inwestycje w jednostkach terytorialnych oddziałują na atrakcyjność inwestycyjną państwa ${ }^{5}$. Należy zauważyć, iż problemem jest efekt wypychania wydatków na inwestycje przez wydatki prawnie zdeterminowane.

Mając w budżecie do dyspozycji większą kwotę środków finansowych, łatwiej wygospodarować pieniądze na inwestycje. Rozpoczynając przedsięwzięcie infrastrukturalne trzeba pamiętać o zabezpieczeniu pieniędzy na jego zakończenie oraz późniejszą eksploatację. Realizacja inwestycji przez jednostki samorządu terytorialnego wymaga zapewnienia stabilnych źródeł ich finansowania.

Dane o udziale wydatków na inwestycje w wydatkach ogółem w jednostkach samorządu terytorialnego są źródłem informacji o tym, jaka część wydatków budżetowych została przeznaczona na działania zaliczone do inwestycyjnych. Odnosząc się do udziału wydatków na inwestycje w wydatkach ogółem ${ }^{6}$ w latach 2007-2014 (tabela 1) należy zaznaczyć, że dla ogółu jednostek samorządu terytorialnego badana wielkość miała najniższy poziom w 2013 r. (18,2\%), a najwyższy w 2009 r. (24,8\%).

4 Ustawa z dnia 27 sierpnia 2009 r. o finansach publicznych, tekst jedn. Dz. U. 2013, nr 0, poz. 885 z późn. zm., art. 236, ust. 2, 4 .

5 K. Soszka-Ogrodnik, Polen verteidigt den ersten Platz im Standort-Ranking in der MOE-Region, www. ahk.pl/medien/wirtschafts-news/einzel/artikel/polen-verteidigt-den-ersten-platz-im-standort-rankingin-der-moe-region/?no_cache=1\&cHash=b7285a1327036992dcf5fc48ed32f034, dostęp 14.11.2015.

6 Dochody, wydatki i wynik budżetów można badać w różnych ujęciach, rozpatrując kwoty: planowane, planowane po zmianach i wykonane. $\mathrm{W}$ niniejszym artykule analizie poddano wartości wykonane. 
$\mathrm{Z}$ analizy poszczególnych kategorii jednostek samorządu terytorialnego wynika, że największy udział wydatków na inwestycje w wydatkach ogółem był w województwach (najlepszy wynik zanotowano w 2009 r. - 47,3\%), gdzie w każdym roku ten odsetek był wyższy niż rezultat ogółu jednostek terytorialnych. Środki te służyły w szczególności wykonywaniu polityki rozwoju województwa. Kolejne, biorąc pod uwagę opisywaną wielkość, były miasta na prawach powiatu w latach 2007-2008 i 2012-2014 lub gminy w latach 2009-2011. Najsłabsze rezultaty w każdym roku uwidoczniły się zaś w powiatach (najgorszy wynik był w latach 2012-2013 i wyniósł 12,3\%).

Tabela 1. Udział wydatków na inwestycje w wydatkach ogółem wg kategorii jednostek samorządu terytorialnego w latach 2007-2014 (w \%)*

\begin{tabular}{|l|c|c|c|c|c|c|c|c|}
\hline \multicolumn{1}{|c|}{ Wyszczególnienie } & 2007 & 2008 & 2009 & 2010 & 2011 & 2012 & 2013 & 2014 \\
\hline Ogół jednostek samorządu terytorialnego & 20,3 & 21,2 & 24,8 & 24,3 & 22,7 & 19,1 & 18,2 & 20,3 \\
\hline Gminy & 18,5 & 20,0 & 22,5 & 24,7 & 22,5 & 17,7 & 16,2 & 17,8 \\
\hline Miasta na prawach powiatu & 21,5 & 21,8 & 21,5 & 21,5 & 20,1 & 19,0 & 17,6 & 19,6 \\
\hline Powiaty & 13,0 & 14,4 & 19,2 & 21,7 & 18,6 & 12,3 & 12,3 & 14,5 \\
\hline Województwa & 35,4 & 34,8 & 47,3 & 37,5 & 39,4 & 35,9 & 38,4 & 42,3 \\
\hline
\end{tabular}

* Kolor szary - w danym roku wynik był wyższy niż rezultat dla ogółu jednostek samorządu terytorialnego. Źródło: opracowanie własne na podstawie Sprawozdania Rady Ministrów z wykonania budżetu państwa w latach 2007-2014. Informacja o wykonaniu budżetów jednostek samorządu terytorialnego, Rada Ministrów.

Zróżnicowanie udziału wydatków na inwestycje w wydatkach ogółem wynika nie tylko z możliwości sfinansowania tych nakładów przy zastosowaniu dostępnych źródeł pozyskania środków, ale również z potrzeb inwestycyjnych poszczególnych jednostek samorządu terytorialnego. Wymagany wysiłek inwestycyjny, w niektórych wypadkach ogromny, jest zależny od możliwości dochodowych jednostek terytorialnych, a zwłaszcza od udziału dochodów własnych w dochodach ogółem.

\section{Dochody własne w gospodarce finansowej jednostek samorządu terytorialnego}

Wśród dochodów budżetowych jednostek samorządu terytorialnego wyróżnia się dochody własne i dochody uzupełniające. Dochody uzupełniające mają postać subwencji ogólnej i dotacji oraz są formą transferu środków finansowych, głównie z budżetu państwa, do budżetów jednostek terytorialnych.

Kategoria dochodów własnych nie została nigdzie zdefiniowana, a polski ustawodawca scharakteryzował ją przez określenie rodzajów wpływów budżetowych należących do tej kategorii. Do dochodów własnych zostały zaklasyfikowane dochody 
z podatków i opłat, dochody z majątku, udziały w podatkach centralnych oraz pozostałe dochody. Warto przy tym zaznaczyć, że dochody własne poszczególnych jednostek samorządu terytorialnego są zróżnicowane, a najkorzystniejsza sytuacja w tym zakresie jest w gminach ${ }^{7}$. Dochody własne powinny być bazą finansową budżetu każdej jednostki samorządu terytorialnego, czyli ich udział w strukturze dochodów ogółem powinien być jak największy, co korzystnie oddziałuje na polepszanie zaplecza finansowego tych podmiotów i tym samym na możliwości realizacji inwestycji samorządowych.

Tabela 2. Struktura dochodów ogółem jednostek samorządu terytorialnego w latach 2007-2014 (w \%)*

\begin{tabular}{|l|c|c|c|c|c|c|c|c|}
\hline \multicolumn{1}{|c|}{ Wyszczególnienie } & 2007 & 2008 & 2009 & 2010 & 2011 & 2012 & 2013 & 2014 \\
\hline \multicolumn{7}{|c|}{ Ogót jednostek samorządu terytorialnego } \\
\hline Dochody własne & 56,4 & 55,0 & 48,6 & 48,3 & 48,8 & 49,1 & 50,0 & 50,7 \\
\hline Dochody uzupełniające & 43,6 & 45,1 & 51,4 & 51,8 & 51,2 & 51,0 & 49,9 & 49,2 \\
\hline \multicolumn{7}{|c|}{ Gminy } \\
\hline Dochody własne & 49,5 & 49,3 & 46,3 & 44,6 & 45,5 & 46,6 & 48,2 & 49,3 \\
\hline Dochody uzupełniające & 50,5 & 50,8 & 53,7 & 55,5 & 54,5 & 53,4 & 51,9 & 50,7 \\
\hline \multicolumn{7}{|c|}{ Miasta na prawach powiatu } \\
\hline Dochody własne & 70,3 & 69,5 & 66,1 & 63,6 & 63,2 & 61,1 & 62,4 & 62,8 \\
\hline Dochody uzupełniające & 29,7 & 30,5 & 34,0 & 36,4 & 36,8 & 38,9 & 37,6 & 37,2 \\
\hline \multicolumn{7}{|c|}{ Powiaty } \\
\hline Dochody własne & 32,2 & 32,4 & 28,4 & 28,2 & 27,7 & 29,4 & 29,9 & 31,3 \\
\hline Dochody uzupełniające & 67,8 & 67,7 & 71,7 & 71,8 & 72,3 & 70,7 & 70,1 & 68,7 \\
\hline \multicolumn{7}{|c|}{ Województwa } \\
\hline Dochody własne & 68,3 & 58,5 & 32,3 & 40,4 & 44,3 & 43,0 & 39,1 & 36,9 \\
\hline Dochody uzupełniające & 31,7 & 41,4 & 67,7 & 59,6 & 55,7 & 57,0 & 60,9 & 63,1 \\
\hline
\end{tabular}

* W niektórych latach liczby nie sumują się do $100 \%$ ze względu na zaokrąglenia.

Źródło: opracowanie własne na podstawie Sprawozdania Rady Ministrów z wykonania budżetu państwa w latach 2007-2014. Informacja o wykonaniu budżetów jednostek samorządu terytorialnego, Rada Ministrów.

Odwołując się do udziału dochodów własnych w dochodach ogółem w latach 2007-2014 (tabela 2) należy zaznaczyć, że dochody własne stanowiły co najmniej połowę budżetu ogółu jednostek samorządu terytorialnego w latach 2007-2008 i 2013-2014, województw w latach 2007-2008 oraz miast na prawach powiatu we wszystkich analizowanych latach. W pozostałych widoczna była przewaga dochodów

7 Szerzej na ten temat w opracowaniu: A. Alińska, M. Dworakowska, Finanse jednostek samorządu terytorialnego, w: Współczesne finanse publiczne, red. A. Alińska, B. Woźniak, Difin, Warszawa 2015, s. 233-238. 
uzupełniających nad dochodami własnymi, która jest niepokojąca zwłaszcza w powiatach, gdzie udział dochodów własnych w dochodach ogółem był na poziomie średnio około 30\% i świadczył o tym, że dochody własne nie są podstawą zasilania finansowego. Najlepszą sytuację budżetową, jeśli analizujemy relację dochodów własnych do dochodów uzupełniających, miały miasta na prawach powiatu, choć $\mathrm{w}$ jednostkach terytorialnych tej kategorii obserwowano zmniejszanie się w latach 2007-2012 udziału dochodów własnych w dochodach ogółem. Analiza przywołanych danych wskazuje na znaczny stopień zależności jednostek samorządu terytorialnego od dochodów uzupełniających, który w każdym charakteryzowanym roku nie dotyczył tylko miast na prawach powiatu.

$\mathrm{W}$ ramach dochodów własnych ogromne znaczenie mają udziały w podatkach centralnych, które płacą obywatele, co powoduje, że skala dochodów mieszkańców oddziałuje na poziom uzyskiwanych z tego tytułu wpływów przez jednostki samorządu terytorialnego. Zamożność mieszkańców ma zatem wpływ na sytuację finansową jednostek terytorialnych. Wszelkie zmiany w zakresie zarówno zasobności ludności, np. w związku z wystąpieniem kryzysu ekonomicznego, jak i liczby mieszkańców, obejmujące przede wszystkim zapobieganie odpływowi, a także przyciąganie ludności oraz inwestorów prywatnych, są odczuwalne w sytuacji budżetowej jednostki terytorialnej.

Ograniczenie dochodów własnych w jednostkach samorządu terytorialnego może być następstwem świadomie stosowanej przez decydentów samorządowych zbyt łagodnej polityki podatkowej realizowanej np. poprzez obniżanie stawek podatków lokalnych oraz brak należytej ściągalności podatków i opłat lokalnych. Stosowanie ulg w podatkach lokalnych powinno się rozpatrywać przynajmniej w dwóch aspektach, z jednej strony może ono sprzyjać zwiększaniu zainteresowania firm prowadzeniem działalności gospodarczej na takim obszarze, $\mathrm{z}$ drugiej zaś poprzez tworzenie nowych miejsc pracy funkcjonujące przedsiębiorstwa będą przyczyniały się do polepszania w przyszłości sytuacji finansowej jednostki samorządu terytorialnego. Należy podkreślić, iż zwiększanie się udziału dochodów własnych w dochodach ogółem jest korzystne, gdyż pozwala generować większy odsetek środków finansowych, który w największym zakresie świadczy o samodzielności finansowej jednostki terytorialnej. Zgromadzone w ten sposób środki mają istotne znaczenie dla realizacji wydatków, w tym tych na inwestycje w jednostkach samorządu terytorialnego. 


\section{Wynik budżetów jednostek samorządu terytorialnego}

Jednostki samorządu terytorialnego w wymagających tego sytuacjach, zwykle związanych z realizacją inwestycji, korzystają z przychodów o charakterze zwrotnym, co oddziałuje na wynik budżetów. Jest to charakterystyczne nie tylko dla tych biedniejszych, ale przede wszystkim dla bogatszych jednostek terytorialnych, które są poważnie zaangażowane w przedsięwzięcia inwestycyjne.

Jeśli wynik budżetów jednostek samorządu terytorialnego jest ujemny, to oznacza on deficyt budżetowy, a w sytuacji, gdy jest dodatni - nadwyżkę budżetową. Każdy z tych typów wyniku budżetów składa się z:

- wyniku bieżącego, czyli różnicy między dochodami bieżącymi a wydatkami bieżącymi; wynik bieżący może wskazywać na obecność nadwyżki operacyjnej bądź deficytu operacyjnego,

- wyniku majątkowego, czyli różnicy między dochodami majątkowymi a wydatkami majątkowymi ; wynik majątkowy świadczy o nadwyżce lub deficycie w części majątkowej.

Analiza problematyki wyniku budżetów wymaga odwołania się do zasady zrównoważenia budżetu w części bieżącej, która obowiązuje jednostki samorządu terytorialnego od $2011 \mathrm{r}$. W myśl tej zasady niemal zawsze zabroniony jest deficyt operacyjny ${ }^{9}$. Obecność ujemnego wyniku budżetów jest dozwolona jedynie w części majątkowej, której specyfika łączy się z realizacją inwestycji, a te wpływają na rozwój jednostek samorządu terytorialnego.

Tabela 3 zawiera dane o obserwowanym w latach 2007-2014 wyniku budżetów z podziałem na wyniki: bieżący i majątkowy. Dodatni wynik budżetów był w gminach tylko w 2007 r. i w 2013 r., w miastach na prawach powiatu i w województwach wyłącznie w 2007 r., w powiatach w latach 2007-2008 i 2012-2013 oraz dla ogółu jednostek samorządu terytorialnego w 2007 r. Pozostałe rezultaty wskazywały na ujemny wynik budżetów, który osiągnął najwyższą wartość w gminach, powiatach i dla ogółu jednostek samorządu terytorialnego w 2010 r., w miastach na prawach powiatu w 2009 r., a w województwach w $2011 \mathrm{r}$. We wszystkich badanych przypadkach wynik bieżący był dodatni i świadczył o nadwyżce operacyjnej, a wynik majątkowy miał znak ujemny i wskazywał na deficyt w części majątkowej. Relacje między wynikami: bieżącym,

8 Wyróżnienie dochodów bieżących i majątkowych oraz wydatków bieżących i majątkowych stało się możliwe dzięki wyodrębnieniu typów dochodów i wydatków zaliczanych do każdej z tych kategorii. Ustawa z dnia 27 sierpnia 2009 r. o finansach publicznych..., op.cit., art. 235, ust. 2-3, art. 236, ust. 2-4.

9 Przypadek, w którym deficyt operacyjny jest dopuszczony, ściśle określają regulacje prawne. Ustawa z dnia 27 sierpnia 2009 r. o finansach publicznych..., op.cit., art. 242, ust. 3. 
majątkowym i ogółem pozwalają stwierdzić, że w wypadku większości obserwacji poprzez zestawienie nadwyżki operacyjnej z ujemnym wynikiem ogółem wskazać można jak poważny deficyt w części majątkowej, czyli łączącej się z wykonywaniem inwestycji, miały badane jednostki terytorialne. Obecność ujemnego wyniku majątkowego jest silnie związana $\mathrm{z}$ wydatkami na inwestycje.

Tabela 3. Wynik budżetów jednostek samorządu terytorialnego w latach 2007-2014 (w mln PLN) *

\begin{tabular}{|c|c|c|c|c|c|c|c|c|}
\hline Wyszczególnienie & 2007 & 2008 & 2009 & 2010 & 2011 & 2012 & 2013 & 2014 \\
\hline \multicolumn{9}{|c|}{ Ogół jednostek samorządu terytorialnego } \\
\hline Wynik ogółem, z tego: & 2258 & -2602 & -12986 & -14970 & -10286 & -3046 & -380 & -2417 \\
\hline Wynik bieżący & 17719 & 17739 & 11960 & 9284 & 10994 & 11626 & 14337 & 16318 \\
\hline Wynik majątkowy & -15461 & -20341 & -24946 & -24253 & -21279 & -14671 & -14717 & -18735 \\
\hline \multicolumn{9}{|c|}{ Gminy } \\
\hline Wynik ogółem, z tego: & 923 & -578 & -5120 & -7430 & -3856 & -84 & 601 & -521 \\
\hline Wynik bieżący & 7196 & 8075 & 6191 & 4687 & 5426 & 6241 & 7340 & 8097 \\
\hline Wynik majątkowy & -6273 & -8653 & -11312 & -12117 & -9283 & -6325 & -6740 & -8618 \\
\hline \multicolumn{9}{|c|}{ Miasta na prawach powiatu } \\
\hline Wynik ogółem, z tego: & 997 & -1720 & -5874 & -5069 & -4650 & -2484 & -736 & -1402 \\
\hline Wynik bieżący & 6794 & 5760 & 2982 & 2503 & 2788 & 2572 & 4152 & 5155 \\
\hline Wynik majątkowy & -5797 & -7480 & -8855 & -7571 & -7438 & -5056 & -4888 & -6556 \\
\hline \multicolumn{9}{|c|}{ Powiaty } \\
\hline Wynik ogółem, z tego: & 85 & 32 & -1071 & -1330 & -507 & 46 & 161 & $-1,5$ \\
\hline Wynik bieżący & 976 & 1099 & 883 & 780 & 1268 & 1092 & 1256 & 1496 \\
\hline Wynik majątkowy & -891 & -1067 & -1955 & -2110 & -1775 & -1045 & -1095 & -1497 \\
\hline \multicolumn{9}{|c|}{ Województwa } \\
\hline Wynik ogółem, z tego: & 253 & -337 & -920 & -1141 & -1272 & -525 & -406 & -493 \\
\hline Wynik bieżący & 2753 & 2804 & 1904 & 1313 & 1512 & 1721 & 1588 & 1571 \\
\hline Wynik majątkowy & -2500 & -3140 & -2824 & -2454 & -2784 & -2245 & -1995 & -2063 \\
\hline
\end{tabular}

* W niektórych latach liczby nie sumują się ze względu na zaokrąglenia.

Źródło: opracowanie własne na podstawie Nadwyżka operacyjna w jednostkach samorzadu terytorialnego w latach 2007-2014, Ministerstwo Finansów.

Trzeba zwrócić uwagę na to, że dłużne instrumenty finansowania przedsięwzięć rozwojowych służą rozszerzeniu możliwych do użycia źródeł kapitału inwestycyjnego w jednostkach samorządu terytorialnego. Co więcej, powinno się przyjąć, że jeśli wybór takich sposobów finansowania inwestycji oraz będąca ich następstwem struktura zobowiązań przyszłych lat nie wywołują negatywnych konsekwencji dla gospodarki budżetowej jednostek terytorialnych, a przyczyniają się do szybszego uzyskania zaplanowanych efektów rzeczowych oraz jakościowych, to przejściowe 
ujemne wyniki budżetów i ich skutki można potraktować jako zjawisko normalne ${ }^{10}$. Zachowanie wysokiego zaangażowania w realizację inwestycji będzie się więc łączyć ze stosowaniem dłużnych form ich finansowania, a będący tego następstwem wzrost zadłużenia związany z dużym wysiłkiem inwestycyjnym musi być dozwolony.

Przynajmniej część inwestycji powinna być finansowana z przychodów o charakterze zwrotnym ${ }^{11}$, ale trzeba też uwzględniać możliwość skorzystania przez jednostki samorządu terytorialnego $\mathrm{z}$ innych zewnętrznych form pozyskiwania środków na takie przedsięwzięcia. Należy zaznaczyć, że niejednokrotnie to instrumenty dłużne pozwalają zgromadzić wkład własny niezbędny jednostkom samorządu terytorialnego, gdy chcą pozyskać bezzwrotne środki z funduszy unijnych i tym samym są one narzędziem poprawy możliwości absorpcyjnych tych podmiotów.

Analiza problematyki wyniku budżetów wymaga zwrócenia szczególnej uwagi na zagadnienie nadwyżki operacyjnej. Jej obecność oznacza, że jednostka samorządu terytorialnego jest w stanie prowadzić następne inwestycje lub spłacać wcześniejsze zadłużenia, co świadczy o dobrej kondycji finansowej samorządu. Wyższa nadwyżka operacyjna daje większe możliwości realizacji przedsięwzięć inwestycyjnych przez jednostkę samorządu terytorialnego ${ }^{12}$. Zdolność do generowania nadwyżki operacyjnej oddziałuje zatem na wydatki na inwestycje w jednostce terytorialnej.

Odnosząc się do szczegółowych danych dotyczących liczby jednostek samorządu terytorialnego z nadwyżką operacyjną i z deficytem operacyjnym w latach 2007-2014 zamieszczonych w tabeli 4, można zaobserwować poważne zwiększenie się liczby jednostek terytorialnych z nadwyżką operacyjną w okresie 2010-2013. Największa liczba gmin z nadwyżką operacyjną uwidoczniła się w 2013 r., a miast na prawach powiatu i powiatów w 2014 r. Wszystkie województwa w latach 2007-2013 osiągnęły również nadwyżkę operacyjną. Spośród ogółu jednostek samorządu terytorialnego najwięcej tych z nadwyżką operacyjną zaobserwowano w 2013 r. - było ich 2770.

Na zwiększanie się liczby jednostek terytorialnych z nadwyżką operacyjną miało wpływ między innymi wprowadzenie zasady zrównoważenia budżetu w części bieżącej. Bardzo dobrze widoczne w ostatnich latach działania podejmowane przez coraz większe grono jednostek samorządu terytorialnego, których celem było osiągnięcie nadwyżki operacyjnej, wynikały też z pracy tych podmiotów na rzecz spełniania

${ }^{10} \mathrm{~K}$. Jarosiński, Finansowanie rozwoju lokalnego i regionalnego $w$ warunkach deficytu budżetowego oraz długu publicznego, w: Zwrotne instrumenty finansowe $w$ procesie stymulowania rozwoju regionalnego, red. A. Alińska, Oficyna Wydawnicza SGH, Warszawa 2013, s. 56.

${ }_{11}$ W. Misterek, Trudności $z$ wykorzystaniem budżetu JST jako narzędzia planistycznego w sytuacji spowolnienia gospodarczego, „Zeszyty Naukowe Uniwersytetu Ekonomicznego w Poznaniu” 2010, nr 141, s. 275 .

${ }^{12}$ M. Poniatowicz, Wplyw kryzysu gospodarczego na systemy finansowe jednostek samorzadu terytorialnego na przykładzie największych miast w Polsce, CeDeWu, Warszawa 2014, s. 139. 
obowiązujących limitów zadłużenia. Obecność nadwyżki operacyjnej pozytywnie wpływa na zdolność do zaciągania nowych zobowiązań finansowych, które pozwalają między innymi realizować kolejne inwestycje.

Tabela 4. Liczba jednostek samorządu terytorialnego z nadwyżką operacyjną i z deficytem operacyjnym w latach 2007-2014

\begin{tabular}{|c|c|c|c|c|c|c|c|c|}
\hline Wyszczególnienie & 2007 & 2008 & 2009 & 2010 & 2011 & 2012 & 2013 & 2014 \\
\hline \multicolumn{9}{|c|}{ Ogół jednostek samorządu terytorialnego } \\
\hline Z nadwyżką operacyjną & 2715 & 2721 & 2585 & 2336 & 2627 & 2707 & 2770 & 2754 \\
\hline$Z$ deficytem operacyjnym & 93 & 87 & 223 & 473 & 182 & 102 & 39 & 55 \\
\hline \multicolumn{9}{|c|}{ Gminy } \\
\hline Z nadwyżką operacyjną & 2350 & 2355 & 2245 & 2014 & 2248 & 2331 & 2387 & 2366 \\
\hline$Z$ deficytem operacyjnym & 63 & 58 & 168 & 400 & 166 & 83 & 26 & 47 \\
\hline \multicolumn{9}{|c|}{ Miasta na prawach powiatu } \\
\hline Z nadwyżką operacyjną & 64 & 64 & 56 & 52 & 61 & 62 & 63 & 65 \\
\hline$Z$ deficytem operacyjnym & 1 & 1 & 9 & 13 & 4 & 3 & 3 & 1 \\
\hline \multicolumn{9}{|c|}{ Powiaty } \\
\hline Z nadwyżką operacyjną & 285 & 286 & 268 & 254 & 302 & 299 & 304 & 308 \\
\hline$Z$ deficytem operacyjnym & 29 & 28 & 46 & 60 & 12 & 15 & 10 & 6 \\
\hline \multicolumn{9}{|c|}{ Województwa } \\
\hline Z nadwyżką operacyjną & 16 & 16 & 16 & 16 & 16 & 16 & 16 & 15 \\
\hline$Z$ deficytem operacyjnym & 0 & 0 & 0 & 0 & 0 & 0 & 0 & 1 \\
\hline
\end{tabular}

Źródło: opracowanie własne na podstawie Nadwyżka operacyjna w jednostkach samorzadu terytorialnego w latach 2007-2014, Ministerstwo Finansów.

Mimo poniesionego w ostatnich latach znacznego wysiłku inwestycyjnego, potrzeby jednostek samorządu terytorialnego w tym zakresie są nadal widoczne. Inwestycje mają znaczenie zarówno dla mieszkańców oraz podmiotów gospodarczych, jak i jednostki samorządu terytorialnego, która wykonuje tego rodzaju przedsięwzięcia, a także jej władz. Realizacja inwestycji przez jednostki terytorialne wymaga uwzględnienia różnorodnych czynników mających wpływ na ich podejmowanie i prowadzenie. Kluczową rolę w tym zakresie odgrywają determinanty finansowe związane z sytuacją budżetową jednostek samorządu terytorialnego. Obejmują one takie wielkości, jak: wydatki na inwestycje, dochody własne, wynik budżetów oraz nadwyżkę operacyjną. Te wyodrębnione czynniki finansowe podlegają możliwości kształtowania przez jednostkę samorządu terytorialnego w ramach rozwiązań określonych w regulacjach prawnych. Uwarunkowania te są zatem przynajmniej w części niezależne od jednostek samorządu terytorialnego. 
Dokonywanie wydatków na inwestycje pozwala zmniejszać różnice w rozwoju jednostek samorządu terytorialnego. Realizacja tych przedsięwzięć wymaga jednak zapewnienia stabilnych źródeł finansowania. Pamiętać przy tym trzeba o efekcie wypychania wydatków na inwestycje przez wydatki prawnie zdeterminowane. Wymagane od jednostek samorządu terytorialnego zaangażowanie w przedsięwzięcia inwestycyjne jest zależne od możliwości dochodowych tych podmiotów. W związku z tym niezwykle istotna jest wielkość udziału dochodów własnych w dochodach ogółem, której zwiększanie ma korzystny wpływ na możliwości realizacji wydatków, w tym tych o charakterze inwestycyjnym. Udział dochodów własnych w dochodach ogółem powinien być możliwie największy, aby środki te stanowiły podstawę finansowania każdej jednostki samorządu terytorialnego i dzięki temu poprawiały możliwości realizacji inwestycji przez te podmioty. Korzystanie przez jednostki samorządu terytorialnego z dłużnych źródeł finansowania inwestycji wymaga uwzględnienia problematyki wyniku budżetów, która jest charakterystyczna szczególnie dla tych samorządów, które są znacznie zaangażowane w realizację inwestycji. Podkreślić przy tym należy, że obecność deficytu w części majątkowej jest dopuszczalna i silnie związana $\mathrm{z}$ wydatkami na inwestycje. Istotne znaczenie $\mathrm{w}$ gospodarce finansowej jednostek samorządu terytorialnego ma obecność nadwyżki operacyjnej, a zdolność do jej generowania wpływa też na wydatki na inwestycje i zdolność do zaciągania nowych zobowiązań oraz świadczy o korzystnej kondycji finansowej samorządu. Większa nadwyżka operacyjna oznacza wyższe możliwości wykonywania inwestycji przez jednostkę samorządu terytorialnego.

\section{Bibliografia}

Alińska A., Dworakowska M., Finanse jednostek samorządu terytorialnego, w: Współczesne finanse publiczne, red. A. Alińska, B. Woźniak, Difin, Warszawa 2015.

Dworakowska M., Determinanty rozwoju aktywności inwestycyjnej miast na prawach powiatu, w: Instrumenty zarzadzania finansami jednostek samorzadu terytorialnego, red. D. Wyszkowska, Wydawnictwo Uniwersytetu w Białymstoku, Białystok 2013.

Jarosiński K., Finansowanie rozwoju lokalnego i regionalnego w warunkach deficytu budżetowego oraz długu publicznego, w: Zwrotne instrumenty finansowe w procesie stymulowania rozwoju regionalnego, red. A. Alińska, Oficyna Wydawnicza SGH, Warszawa 2013.

Misterek W., Trudności z wykorzystaniem budżetu JST jako narzędzia planistycznego w sytuacji spowolnienia gospodarczego, „Zeszyty Naukowe Uniwersytetu Ekonomicznego w Poznaniu” 2010, nr 141.

Nadwyżka operacyjna w jednostkach samorządu terytorialnego w latach 2007-2014, Ministerstwo Finansów. 
Poniatowicz M., Wplyw kryzysu gospodarczego na systemy finansowe jednostek samorzadu terytorialnego na przykładzie największych miast w Polsce, CeDeWu, Warszawa 2014.

Soszka-Ogrodnik K., Polen verteidigt den ersten Platz im Standort-Ranking in der MOE-Region, www.ahk.pl/medien/wirtschafts-news/einzel/artikel/polen-verteidigt-den-ersten-platzim-standort-ranking-in-der-moe-region/?no_cache=1\&cHash=b7285a1327036992dcf5fc48ed32f034, dostęp 14.11.2015.

Sprawozdania Rady Ministrów z wykonania budżetu państwa w latach 2007-2014. Informacja o wykonaniu budżetów jednostek samorządu terytorialnego, Rada Ministrów.

Ustawa z dnia 27 sierpnia 2009 r. o finansach publicznych, tekst jedn. Dz. U. 2013, nr 0, poz. 885 z późn. zm.

Wojciechowski E., Zarzadzanie w samorzadzie terytorialnym, Difin, Warszawa 2012. 